\title{
Soil Properties and Crop Yield under Boron Nutrition Management for Paddy crop in Coastal Karnataka, India
}

\author{
S. M. Jayaprakash ${ }^{1 *}$, S. U. Patil ${ }^{2}$, T. H. Ranjith ${ }^{1}$, V. Jayaprakash ${ }^{3}$ \\ and K. V. Sudhir Kamath ${ }^{4}$ \\ ${ }^{1}$ Department of Soil Science and Agricultural Chemistry, ZAHRS, Brahmavar, India \\ ${ }^{2}$ Associate Director of Research, ZAHRS, Brahmavar, India \\ ${ }^{3}$ Krishi Vigyan Kendra, Brahmavar, Udupi, India \\ ${ }^{4}$ Department of Agronomy ZAHRS, Brahmavar, India \\ *Corresponding author
}

A B S T R A C T

Keywords

Kharif, HWE-

Boron, Borax,

paddy, package

Article Info

Accepted:

15 January 2020

Available Online:

10February 2020
A field experiment was conducted during kharif of 2014 and 2015 at Zonal Agricultural and Horticultural Research Station, Brahmavar, Udupi district, Karnataka, to investigate the effect of Boron nutrition management on soil properties, soil available nutrients yield of paddy under different Boron nutrient management studies. The experiment was laid out in RCBD design with four replications and five treatments involving different levels of Boron applications in comparison to package of practice as control. After two years of experimentation, the study revealed that, significantly higher HWE-Boron was observed in treatment T5: T2+10 kg Borax, followed by the treatment T4: T2 $+7.5 \mathrm{~kg}$ Borax and T3: T2 $+5 \mathrm{~kg}$ Borax. Grain yield and straw yield was found significantly higher in the treatment which received boron nutrient when compared to control.

\section{Introduction}

In India rice is grown in 43.86 million ha, the production level is 104.80 million tones and the productivity is about $2390 \mathrm{~kg} / \mathrm{ha}$ (Agricultural Statistics at a glance- 2015). It is grown under diverse soil and climatic conditions the productivity level of rice is low compared to the productivity levels of many countries in the world. Also about $90 \%$ of the cultivated land belongs to Marginal, Small and
Medium farmers which is another constrain in increasing the productivity of rice in the country. Rice is one of the most important food crops and feeds more than 60 per cent population of India. The area under rice crop was $30.81 \mathrm{million} / \mathrm{ha}$ in 1950-51 which has increased to 43.86 million hectares during 2014-15 which is nearly 142 per cent higher. The rice production has registered an appreciable increase from 20.58 million tonnes in 1950-51 to 104.86 million tonnes 
during 2014-15, which is nearly 5 times. The yield was $668 \mathrm{~kg} / \mathrm{ha}$ in 1950-51 which has increased to $2390 \mathrm{~kg} / \mathrm{ha}$ during 2014-15. Major share of rice production is in Kharif season (National food Security mission report 2016).

Boron is most soluble under acid conditions. It apparently occurs in acid soils in part as boric acid (H3BO3), which is readily available to plants. In quite acid sandy soils, soluble B fertilizers may be leached downward with comparable ease. In heavier soils, especially if they are not too acid, this rapid leaching does not occur. At higher $\mathrm{pH} \mathrm{B}$ is less easily utilized by plants. This may be due to lime induced fixation of this element by clay and other minerals, since the $\mathrm{Ca}$ and $\mathrm{Na}$ borates are reasonably soluble. In any case over liming can and often does result in a deficiency of B. B is held in organic combinations from which it may be released for crop use. The content of this nutrient in the top soil is generally higher than that in the subsoil. This may in part account for the noticeably greater B deficiency in periods of dry weather. Apparently, during drought periods plant roots are forced to exploit only the lower soil horizons, where the $\mathrm{B}$ content is quite low. When the rains come, plant roots again can absorb B from the topsoil, when its concentration is highest.

\section{Materials and Methods}

A field experiment was conducted during kharif season of 2014 and 2015 at Zonal Agricultural and Horticultural Research Station, Brahmavar, Udupi district, Karnataka, the effect of Boron nutrition management on soil properties, soil available nutrients yield of paddy under different Boron nutrient management studies. The experimental site is situated between $74^{0} 45^{\prime}$ to $74^{0} 46^{\prime}$ East longitude and $13^{\circ} 24^{\prime} 45^{\prime}$ ' to $13^{\circ} 25^{\prime}$ North latitude and an altitude of 25 meters above mean sea level. Soil type is sandy loam in texture and $\mathrm{pH}$ was acidic (5.20). The soil was medium in available nitrogen $(348.70 \mathrm{~kg}$ ha$1)$, high in available phosphorus $(88.57 \mathrm{~kg}$ ha1) and medium in available potassium (74.43 $\mathrm{kg}$ ha-1). The organic carbon content was high $(1.031 \%)$ in range. MO-4 (Red rice) a popular medium duration variety was transplanted in July with a spacing of $20 \mathrm{~cm}$ X $10 \mathrm{~cm}$. Experiment included five treatments consisted of $\mathrm{T}_{1}: 100 \%$ NPK (POP; N:P:K= 60:30:60 kgs/ha), $\mathrm{T}_{2}: \mathrm{T}_{1}+2.5 \mathrm{~kg}$ Borax, $\mathrm{T}_{3}: \mathrm{T}_{2}+5 \mathrm{~kg}$ Borax, $\mathrm{T}_{4}: \mathrm{T}_{2}+7.5 \mathrm{~kg}$ Borax, $\mathrm{T}_{5}: \mathrm{T}_{2}+10 \mathrm{~kg}$ Borax. Data on yield (biological and economical) was recorded from individual plots at harvest and converted to $\mathrm{kg} / \mathrm{ha}$. Composite soil sample were used to assess soil nutrient status. Standard statistical methods were used for comparing the treatment means.

\section{Results and Discussion}

The results obtained from two years of experiment is pooled and anlysed using standard statistical tools. Results pertaining to the effect of Boron nutrition management soil properties and soil available nutrients is presented in Table 1 and 2. Results shown that there is no significant difference was observed among the treatments in case of in $\mathrm{pH}$, electrical conductivity, organic carbon, soil available Phosphorus, potassium, exchangeable calcium, Magnesium and available Sulfur.

It is quite evident from the result that boron nutrient management showed significant results. A significant higher hot water extractable Boron was obtained in treatment T5: T2 + $10 \mathrm{~kg}$ Borax (0.440 ppm) and T4: T2 $+7.5 \mathrm{~kg}$ Borax $(0.425 \mathrm{ppm})$, followed by T3: $\mathrm{T} 2+5 \mathrm{~kg} \operatorname{Borax}(0.408 \mathrm{ppm})$. Similar observations were resulted by Dolui and Sarkar (2001) Narendra babu., (2011) Ranjit (2005) Mukhopadhyay and Das (2001) and Sarkar et al.,(2008). 
Int.J.Curr.Microbiol.App.Sci (2020) 9(2): 2239-2243

Table.1 Soil properties of the experimental site (2015)

\begin{tabular}{|c|c|c|c|c|c|c|c|c|c|c|}
\hline \multicolumn{2}{|c|}{ Treatments Details } & \multirow{3}{*}{$\begin{array}{c}\mathbf{p H} \\
5.20\end{array}$} & \multirow{3}{*}{$\begin{array}{c}\text { EC } \\
\mathrm{dSm}^{-1} \\
0.056\end{array}$} & \multirow{3}{*}{$\begin{array}{c}\text { OC } \\
\% \\
1.031\end{array}$} & \multirow{3}{*}{$\begin{array}{l}\text { Av. P } \\
\begin{array}{c}\mathrm{Kg} / \mathrm{h} \\
\mathrm{a} \\
88.57\end{array}\end{array}$} & \multirow{3}{*}{$\begin{array}{c}\text { Av. } \\
\mathbf{K} \\
\mathrm{Kg} / \mathrm{h} \\
\mathrm{a} \\
74.43\end{array}$} & Ex. Ca & Ex. Mg & \multirow{3}{*}{$\begin{array}{l}\text { Av. S } \\
\text { kg/ha } \\
17.24\end{array}$} & \multirow{3}{*}{$\begin{array}{c}\text { HWE-B } \\
(\mathrm{ppm}) \\
0.381\end{array}$} \\
\hline & & & & & & & \multicolumn{2}{|c|}{ C.mol $\left(\mathrm{P}^{+}\right) \mathrm{kg}^{-1}$ soil } & & \\
\hline & Initial & & & & & & 0.806 & 0.452 & & \\
\hline $\begin{array}{l}T \\
1\end{array}$ & $\begin{array}{l}100 \% \text { NPK (POP) } \\
(\mathrm{N}: \mathrm{P}: \mathrm{K}=60: 30: 60 \mathrm{kgs} / \mathrm{ha})\end{array}$ & 5.11 & 0.058 & 1.123 & 93.91 & 67.18 & 0.795 & 0.308 & 16.87 & 0.361 \\
\hline $\begin{array}{l}\mathbf{T} \\
2\end{array}$ & $\mathrm{~T}_{1}+2.5 \mathrm{~kg}$ Borax & 5.39 & 0.052 & 1.077 & 93.81 & 65.78 & 0.822 & 0.402 & 18.83 & 0.403 \\
\hline $\mathbf{T}$ & $\mathrm{T}_{2}+5.0 \mathrm{~kg}$ Borax & 5.15 & 0.063 & 1.060 & 94.27 & 65.07 & 0.866 & 0.385 & 17.66 & 0.453 \\
\hline T & $\mathrm{T}_{2}+7.5 \mathrm{~kg}$ Borax & 5.23 & 0.053 & 1.031 & 90.68 & 64.57 & 0.843 & 0.367 & 18.01 & 0.473 \\
\hline $\mathbf{T}$ & $\mathrm{T}_{2}+10.0 \mathrm{~kg}$ Borax & 5.23 & 0.067 & 1.017 & 94.69 & 64.97 & 0.837 & 0.379 & 17.05 & 0.488 \\
\hline & SEM \pm & --- & --- & --- & --- & --- & --- & --- & --- & 0.011 \\
\hline & $\mathrm{CV}$ & --- & --- & --- & --- & --- & --- & --- & --- & 4.507 \\
\hline & $\mathrm{CD}(5 \%)$ & NS & NS & NS & NS & NS & NS & NS & NS & 0.032 \\
\hline
\end{tabular}

Table.2 Soil properties of the experimental site (2016)

\begin{tabular}{|c|c|c|c|c|c|c|c|c|c|c|}
\hline \multirow{2}{*}{\multicolumn{2}{|c|}{ Treatments Details }} & \multirow{3}{*}{$\begin{array}{c}\mathbf{p H} \\
5.22\end{array}$} & \multirow{3}{*}{$\begin{array}{c}\mathbf{E C} \\
\mathrm{dSm}^{-1} \\
0.068\end{array}$} & \multirow{3}{*}{$\begin{array}{c}\text { OC } \\
\% \\
1.021\end{array}$} & \multirow{3}{*}{$\begin{array}{l}\text { Av. P } \\
\text { Kg/ha } \\
63.49\end{array}$} & \multirow{3}{*}{$\begin{array}{l}\text { Av. K } \\
\mathrm{Kg} / \mathrm{ha} \\
63.25\end{array}$} & Ex. Ca & Ex. Mg & \multirow{3}{*}{$\begin{array}{l}\text { Av. S } \\
\text { kg/ha } \\
15.43\end{array}$} & \multirow{3}{*}{$\begin{array}{c}\text { HWE-B } \\
\text { (ppm) } \\
0.296\end{array}$} \\
\hline & & & & & & & \multicolumn{2}{|c|}{ C.mol $\left(\mathrm{P}^{+}\right) \mathrm{kg}^{-1}$ soil } & & \\
\hline & Initial & & & & & & 0.782 & 0.346 & & \\
\hline $\mathbf{T}_{1}$ & $\begin{array}{l}100 \% \text { NPK (POP) } \\
(\mathrm{N}: \mathrm{P}: \mathrm{K}=60: 30: 60 \mathrm{kgs} / \mathrm{ha})\end{array}$ & 5.28 & 0.081 & 1.019 & 64.53 & 58.77 & 0.815 & 0.350 & 16.69 & 0.304 \\
\hline $\mathbf{T}_{2}$ & $\mathrm{~T}_{1}+2.5 \mathrm{~kg}$ Borax & 5.16 & 0.058 & 0.994 & 66.06 & 60.00 & 0.743 & 0.417 & 17.32 & 0.334 \\
\hline $\mathbf{T}_{3}$ & $\mathrm{~T}_{2}+5.0 \mathrm{~kg}$ Borax & 5.28 & 0.052 & 1.011 & 65.53 & 62.05 & 0.847 & 0.315 & 16.73 & 0.363 \\
\hline $\mathbf{T}_{4}$ & $\mathrm{~T}_{2}+7.5 \mathrm{~kg}$ Borax & 5.23 & 0.049 & 1.045 & 68.76 & 61.78 & 0.760 & 0.339 & 17.05 & 0.376 \\
\hline $\mathbf{T}_{5}$ & $\mathrm{~T}_{2}+10.0 \mathrm{~kg}$ Borax & 5.16 & 0.054 & 1.084 & 67.20 & 61.82 & 0.843 & 0.317 & 17.62 & 0.392 \\
\hline & $\mathrm{SEM} \pm$ & --- & --- & --- & --- & --- & --- & --- & --- & 2.128 \\
\hline & $\mathrm{CV}$ & --- & --- & --- & --- & --- & --- & --- & --- & 6.385 \\
\hline & $\mathrm{CD}(5 \%)$ & NS & NS & NS & NS & NS & NS & NS & NS & 0.037 \\
\hline
\end{tabular}


Table.3 Effect of boron nutrition on grain and straw yield (kgs/ha) of paddy

\begin{tabular}{|c|c|c|c|c|c|c|c|}
\hline & \multirow[t]{2}{*}{ Treatments } & \multicolumn{2}{|c|}{ Grain Yield } & \multirow[t]{2}{*}{ Pooled } & \multicolumn{2}{|c|}{ Straw yield } & \multirow[t]{2}{*}{ Pooled } \\
\hline & & 2015 & 2016 & & 2015 & 2016 & \\
\hline $\mathbf{T}_{1}$ & $\begin{array}{l}\text { 100\% NPK (POP; N:P:K=60:30:60 } \\
\text { kgs/ha) }\end{array}$ & 5898 & 5800 & 5849 & 7055 & 6875 & 6956 \\
\hline $\mathbf{T}_{2}$ & $\mathrm{~T}_{1}+2.50 \mathrm{~kg}$ borax soil application & 6395 & 6263 & 6329 & 7128 & 7368 & 7248 \\
\hline $\mathbf{T}_{3}$ & $\mathrm{~T}_{2}+5.00 \mathrm{~kg}$ borax soil application & 6528 & 6418 & 6473 & 7498 & 7360 & 7429 \\
\hline $\mathbf{T}_{4}$ & $\mathrm{~T}_{2}+7.50 \mathrm{~kg}$ borax soil application & 6600 & 6525 & 6562.5 & 7288 & 7445 & 7366.5 \\
\hline $\mathbf{T}_{5}$ & $\mathrm{~T}_{2}+10.00 \mathrm{~kg}$ borax soil application & 6460 & 6537 & 6498.5 & 7530 & 7498 & 7514 \\
\hline & SEm \pm & 79.449 & 92.324 & 88.447 & ---- & ---- & ---- \\
\hline & $\mathrm{CV}$ & 2.409 & 2.870 & 2.451 & ---- & ----- & ---- \\
\hline & $\mathrm{CD}(0.05)$ & 235.965 & 279.743 & 261.74 & NS & NS & NS \\
\hline
\end{tabular}

Results pertaining to the Boron nutrition management on grain and straw yield of paddy is presented in Table 3. After two years of experiment, the data obtained on grain and straw yield is pooled and analyzed statistically. Result shows that the application of lime and secondary nutrients along with recommended dose of nutrients had very good impact to improve the soil available nutrients that resulted in higher grain yield contrastingly showed non significant difference in case of straw yield. Significantly higher grain yield as obtained in the treatment $\mathrm{T} 4: \mathrm{T} 2+7.5 \mathrm{~kg}$ Borax $(6562.5$ kg ha-1), T5 : T2 + $10 \mathrm{~kg}$ Borax $(6498.5 \mathrm{~kg}$ ha-1) and T3: T2 + $5 \mathrm{~kg}$ Borax (6473 kg ha-1) followed by T2: T1+2.5 kg Borax $(6329 \mathrm{~kg}$ ha-1) Similar observations were resulted by Saleem et al.,(2011) Dharmendra (2012) Hossain et al., (2011) Shimpei et al., (2011) and Sheelarani 2013.

From two years of investigation reveals that application of recommended dose of fertilizer along with borax at $7.5 \mathrm{~kg} \mathrm{ha}^{-1}$ and $10 \mathrm{~kg} \mathrm{ha}^{-1}$ recorded significantly higher HWE-Boron and also improved soil available nutrients over other treatments. In any case over liming can and often does result in a deficiency of B This may in part account for the noticeably greater B deficiency in periods of dry weather. Apparently, during drought periods plant roots are forced to exploit only the lower soil horizons, where the B content is quite low. When the rains come, plant roots again can absorb B from the topsoil, when its concentration is highest. Which resulted in higher nutrient uptake by the crop, thus make favourable influence of soil available nutrients. Which ultimately influenced the significant increase in HWE-Boron and grain yield.

\section{References}

Agricultural Statistics at a Glance, 2015, Directorate of Economics and Statistics, Department of Agriculture and Cooperation, Ministry of Agriculture, Government of India.

National food Security mission report 2016.

Dharmendra . 2012, Boron Fertilization of Rice with Soil and Foliar Applications. Int. J. Agri. Biol. 8 (6): 1-4

Dolui, A.K. AND Sarkar, R., 2001, Influence of nature of acidity on lime requirement of two Inceptisol and an Alfisol. $J$. Indian Soc. Soil Sci., 49: 195-198.

Hossain, A., Sarker, M.A.Z., Hakim., M.A. Islam, T. and Ali, M. E. 2011. Int. J. Agril. Res. Innov. \& Tech. 1 (1\&2): 9- 
15.

Mukhopadhyay, D. and Das, D.K, 2001. Effect of organic matter, lime and zinc application on the availability of iron and manganese in acid soils under submergence. J. Indian Soc Soil Sci., 49 (1):80-84.

Narendra Babu, B., 2011. Studies on distribution of calcium, magnesium, sulphur and boron in soils of selected agro climatic zones of Karnataka. M.Sc(Agri) Thesis, UAS, Bengaluru.

Ranjit, R., 2005. Response of groundnut genotypes to lime and phosphorus levels in coastal alluvial soil of north Karnataka, M. Sc. (Agri) Thesis, UAS, Dharwad.

Saleem, M., Khanif, M., Ishak, F., Samsuri, A.W. and Hafeez, B. 2011. Boron fertilizers borax and colemanite application on rice and their residual effect on the following crop cycle. $J$. Japanese Soc. Soil Sci Plt Nutr., 36: 180-181.

Sarkar, D., Biswapati Mandal and Debases Mazumdar. 2008. Plant availability of boron in acid soils as assessed by different extractants. J. Plt Nutr. Soil Sci., 171:249-254.

Sheelarani, 2013. Effect of calcium and magnesium application on yield of crops and properties of low $\mathrm{pH}$ soils deficient in available boron in coastal and eastern dry zones of Karnataka M. Sc. (Agri) Thesis, UAS, Bangalore.

Shimpei, U. and Toru, F., 2011. Significant contribution of boron stored in seeds to initial growth of rice seedlings. Plant and Soil, 34:435-442.

\section{How to cite this article:}

Jayaprakash, S. M., S. U. Patil, T. H. Ranjith, V. Jayaprakash and Sudhir Kamath, K. V. 2020. Soil Properties and Crop Yield under Boron Nutrition Management for Paddy crop in Coastal Karnataka, India. Int.J.Curr.Microbiol.App.Sci. 9(02): 2239-2243. doi: https://doi.org/10.20546/ijcmas.2020.902.253 